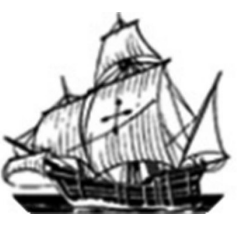

\title{
A TRADIÇÃO REPRESENTADA: VOZ, ORALIDADE E PERFORMANCE NA CANTORIA SOBRE PATATIVA DO ASSARÉ
}

\author{
Rafael Hofmeister de Aguiar (U. FEEVALE) ${ }^{1}$ \\ Daniel Conte (U. FEEVALE) ${ }^{2}$ \\ Valter Ribeiro (UNISINOS) ${ }^{3}$
}

\begin{abstract}
RESUMO: O presente trabalho tem por objetivo analisar a cantoria que se constrói em torno da obra poética de Patativa do Assaré. O corpus da pesquisa é composto pelo registro em vídeo do "Encontro de cantadores" ocorrido junto à casa em que o poeta morou em Serra de Santana (Assaré-CE) durante VIII Patativa do Assaré em Arte e Cultura em março de 2012 e de um repente executado por Mané do Cego e Miceno Pereira na rádio Assaré FM em junho de 2011, quando da nossa pesquisa de campo sobre o poeta. A abordagem segue duas perspectivas que se retroalimentam. A primeira está calcada na representação e difusão do mito sobre a figura de Patativa do Assaré, evidenciando uma imagem não só do sujeito como também de sua obra poética. Essa perspectiva tem como referencial teórico os estudos de Carvalho (2009) e Feitosa (2003) sobre o poeta de Assaré. Enquanto Feitosa (2003) aponta para a construção do mito em torno da figura do poeta, Carvalho (2009, p. 145) registra a existência de uma comunidade poética em Serra de Santana, em que "Patativa seria uma espécie de pai dos poetas da Serra", o que é expressa pela performance dos cantores que faz parte do nosso corpus. A partir de Zumthor (2000, 2010), a segunda linha de abordagem volta-se para o fazer artístico e poético dos cantadores. Através da performance, advém uma tradição do improviso na lusofonia, que de acordo com Cascudo (s/d) remonta aos pastores da Grécia clássica, ademais da influência da cultura árabe, segundo Soler (1978). Nesse sentido, procura-se identificar como a voz dos repentistas se manifesta em performance interagindo com o auditório ali presente, tornando-se o público uma espécie de coautor dos versos proferidos. Há manifesta uma oralidade primária que se une à mitificação de Patativa, através da imagem do poeta que compõe seus poemas por meio de um exercício mnemônico, em que a memória funciona não só como forma de produção, como também de conservação da obra poética, satisfazendo as cinco fases da existência do poema na acepção de Zumthor (2010) em Introdução à poesia oral.
\end{abstract}

PALAVRAS-CHAVE: Patativa do Assaré; Poesia; Oralidade.

RESUMEN: Este estudio tiene como objetivo analizar el canto que se construye en torno a la obra poética de Patativa do Assaré. El corpus de investigación se compone de la grabación en video del "Encontro de cantadores" que se produjo junto a la casa donde el poeta vivió en Serra de Santana (Assaré-CE) durante el VIII Patativa do Assaré em Arte e Cultura en marzo de 2012 y de un repente a cargo de Mané do Cego y Miceno Pereira en la radio Assaré FM, en junio de 2011, cuándo de nuestra investigación in loco sobre el poeta. El enfoque sigue dos perspectivas que se retroalimentan. La primera se basa en la representación y difusión del mito sobre la figura del Patativa do Assaré, que muestra una imagen no sólo del sujeto, sino también de su poesía. Esta perspectiva tiene como base teórica los estúdios de Carvalho (2009) y Feitosa ( 2003 ) sobre el poeta de Assaré. Mientras Feitosa ( 2003 ) apunta a la construcción del mito en torno a la figura del poeta, Carvalho (2009. p.145) registra la existencia de una comunidad poética en Serra de Santana, en la que "Patativa seria uma espécie de pai dos poetas da Serra", que se expresa por la actuación de cantadores, parte de nuestro corpus. Desde Zumthor $(2000,2010)$, la segunda línea de aproximación se convierte en lo artístico y poético de los cantadores. A través de la performance, se muestra una tradición de la improvisación en lengua portuguesa, que según Cascudo (s/d) se remonta a los pastores de la Grecia clásica, además de la influencia de la cultura árabe, de acuerdo con Soler (1978). En consecuencia, tratamos de identificar como la voz de los repentistas se

\footnotetext{
${ }^{1}$ Mestre em Processos e Manifestações Culturais pela Universidade Feevale. Professor-tutor das disciplinas de Antropologia, Filosofia e Semiótica na Universidade Feevale.

${ }^{2}$ Doutor em Literaturas Brasileira, Portuguesa e Luso-Africanas pela Universidade Federal do Rio Grande do Sul (UFRGS). Professor do Curso de Letras e do Mestrado em Processos e Manifestações Culturais na Universidade Feevale.

${ }^{3}$ Acadêmico do curso de Letras na Universidade do Vale do Rio dos Sinos.
} 
manifiesta en el desempeño (performance) interactuando con el público presente allí, convirtiéndose en una especie de público co-autor de los versos pronunciados. Hay manifiesta una oralidad primaria que une a la mitificación de Patativa, a través de la imagen del poeta que compone sus poemas de un ejercicio mnemotécnico, en el que la memoria funciona no sólo como un medio de producción, así como la conservación de la poesía, satisfaciendo las cinco fases de la existencia en el sentido de Zumthor ( 2010 ) en su obra Introducción a la poesía oral.

PALABRAS CLAVE: Patativa do Assaré; Poesía; Oralidad.

\section{1. À guisa de introdução: comunidade poética de Serra de Santana e a fonte patativana}

Ao vasculharmos a fortuna crítica sobre a poética de Patativa do Assaré, deparamonos com significativas investigações, contudo, nos estudos de Carvalho (2009), encontramos a afirmação que da Serra de Santana - local da Zona Rural do município de Assaré-CE em que Patativa viveu a maior parte de sua vida - surgiu um número considerável de poetas. $\mathrm{O}$ autor nos diz que em um levantamento prévio, elencam-se aproximadamente vinte e cinco. Ademais observa que esse grupo, que surge em torno do poeta maior de Assaré, é chamado de Comunidade poética de Serra de Santana. Esses poetas "brotaram" da Serra "como a herança patativana; como se Patativa permanecesse no canto que outros enunciam, como se o poeta se multiplicasse em outras vozes, em uma polifonia sertaneja" (CARVALHO, 2009, p. 145).

Uma amostragem dessa multiplicação de vozes poéticas foi possível perceber durante os dois momentos em que se realizou a pesquisa de campo em Assaré (junho de 2011 e março de 2012). Naqueles dois momentos, constatou-se in loco a influência daquilo que Feitosa (2003) definiu como fonte patativa. De todo o material colhido na experiência da pesquisa (cordéis, livros, imagens, entre outros), optamos por tomar como corpus três repentes que falam sobre a figura patativana e que foram coletados durante o trabalho de campo. Por esse motivo, primeiramente, voltamo-nos para a composição imagética que os cantadores constroem de Patativa do Assaré para, logo a seguir, abordar as questões acerca da voz, da oralidade e da performance na execução artística dos quatro cantadores registrados em pleno fazer poético: Mané do Cego e Miceno Pereira, em junho de 2011, na rádio Assaré FM; e Lorival Pereira e Zé Soares, em março de 2012, no Encontro de repentistas durante o VIII Patativa do Assaré em Arte e Cultura.

\section{A pessoa, o poeta e o mito: a imagem de Patativa nos repentes coletados}

Das legitimações da ossatura social e de seu imaginário, a figuração mítica é a que solidifica/justifica as relações entre causa e efeito dos mecanismos sociais. É a que melhor 
organiza o reconhecimento do campo imagético e exemplifica a semântica dos movimentos culturais, tornando-a dizível em seu contexto. A seguir, uma breve síntese da acepção do mito para que se entenda os sentidos e o como foi projetado em Patativa a funcionalidade mítica pela Comunidade poética de Serra de Santana.

\subsection{Para contextualizar o mito}

$\mathrm{O}$ anseio de respostas para questões cruciais da existência fez do Homem um ser em eterna diáspora subjetiva, sempre inconstante e em busca de uma explicação para sua origem. Uma das características do surgimento dos mitos, exercedores de funções práticas na ossatura social e explicador pragmático, é justificar tudo aquilo que não se pode racionalmente relacionar a fenômenos lógico-racionais. Então, o que foge à razão encontra nos rituais - (cerimônias) fundantes - a invocação de um signo arquetípico que vai edificar as imagens gestadas desde o imaginário social.

Essas imagens exemplares trazem os modelos comportamentais como sendo já uma herança cultural, um mosaico de representações sígnicas que vai edificar a referência social. E entenda-se, aqui, arquétipos por "certos esquemas estruturais, pressupostos estruturais de imagens (que existem no âmbito do inconsciente coletivo e que, possivelmente, são herdados biologicamente) enquanto expressão concentrada de energia psíquica, atualizada em objeto" (MELETÍNSKI, 2002, p. 20). Assim, ao evocar a presença desses arquétipos sacros, o Homem se torna contemporâneo deles, apropriando-se dos modelos trazidos.

Se hoje a ciência e a tecnologia movem a humanidade e com suas associações se busca a explicação para as mais comuns das ocorrências mundanas, é possível dizer que a mitologia dos povos arcaicos os levou a sustentar-se em uma realidade que, muitas vezes, se apresentava de forma hostil. O certo é que urge a explicação do mundo e de suas manifestações e que, a reboque, vêm as possibilidades trazidas pela rede imaginária, pelo substrato simbólico regedor das referências; tudo se condensa na síntese dos valores sociais retratados. A visão de um mundo pré-lógico, pré-racionalista, a visão de uma organização social que vive sob a égide do tempo cíclico se ergue, sempre, alicerçada em um silêncio construtor, em um movimento de sentido que é perpassado por aqueles iniciados ritualisticamente. Todo mito é "introduzido", e alguns teóricos tratam como "anunciado", por uma récita que evidencia as possibilidades dessa semântica de sentido. Isso porque nas sociedades autóctones erguidas sobre uma condição mítico-sacral, ele tem um papel enaltecedor e codificador das crenças, salvaguardando os princípios morais ao passo que 
oferece regras para a orientação dos atores sociais. Consoante ao exercício desse papel, pode explicar a condição de um ser que coexiste naquele universo, e usá-lo como exemplo concreto, ditar seus valores morais ao mostrar as consequências das práticas profanas.

Estamos, então, legitimando através do conhecimento empírico, a razão da ordem natural das coisas que constituem a trajetória destas organizações, dentro de seu entorno imaginário. E ao nos referirmos a mitos, não estamos, seguramente, nos referindo a escalas de superioridade ou inferioridade hierárquicas, mas a necessidades que surgem do embate da vida do Homem com a História, a problemas e questionamentos sociais que são abarcados miticamente.

O mito, esse "nada que é tudo", como afirmou o poeta Fernando Pessoa, trabalha com o desconhecido legitimado pelo coletivo, trata um objeto que a princípio não temos palavras para explicá-lo, então, habitamos sua significação sacra e o tornamos sacro em oposição a um outro-algo (o profano) que será sua sombra, fruto da transgressão. De acordo com Armstrong (2005) a "mitologia em geral é inseparável do ritual. Muitos mitos não fazem sentido separados de uma representação litúrgica que lhes dá vida, sendo incompreensíveis num cenário profano" (p. 09). O que a autora quer dizer é que os mitos perdem sua função elementar se [des]conjugados do cerimonial que os eleva à condição de arquétipo modelar, aceito no coletivo social. A função pragmática do mito consiste na fundamentação da cooperação entre natureza e sociedade, normatizando funcionalmente essa mesma sociedade, transformando o caos em cosmos e explicando, consequentemente, a ordem social e cósmica (ELIADE, 1992).

Antes de discutirmos a função simbólico-metafórica do mito em Patativa do Assaré, é bom deixar evidente que ele traz em sua essência duas características fundantes: uma é o silêncio dos inapropriados, pois a palavra que detém a constituição sígnica não pode ser vulgarizada, Cassirer (1972). A outra, é sua eficácia que vai atribuir ao mito o valor de verdade, uma visão outra, mais profunda do que a apresentada na realidade, como ensina Eliade (1994). A "modernidade" composta pelos remanescentes do iluminismo europeu ignora, generalizando a afirmação, o alicerce sustentador dessas sistematizações iniciais de psicologia, pois não leva em conta que

As histórias de deuses e heróis que descem às profundezas da terra, lutando contra monstros e atravessando labirintos, trouxeram à luz os mecanismos misteriosos da psique, mostrando às pessoas como lidar com suas crises íntimas. Quando Freud e Jung iniciaram a moderna investigação da alma, voltaram-se instintivamente para a 
mitologia clássica para explicar suas teorias, dando uma nova interpretação a velhos mitos (ARMSTRONG, 2005, p. 15).

O que se pode dizer é que os Homens criaram mitos para explicar o mundo e a si próprios, os rituais e as récitas vão sustentar suas afirmações e a palavra toma uma importância singular na liturgia mítica, uma vez que dá vida aos arquétipos - herança psíquica e cultural que dá origem aos nossos valores morais. Essa característica, a da palavra habitada de sentido que se eleva soberana e significativa entre os homens - importantíssima dentro das culturas arcaicas - é totalmente avassalada pela verborragia inestancável semeada pela aridez significadora da não apropriação ritual, negando o poder transformacional do signo do qual vai falar Cassirer, 1972. Assim, ao se pensar em mito, logo temos que nos reportar ao rito, elemento fundamental na sustentação da imagem mítica. Ao se pensar em mito, logo temos de entendê-lo como um ingrediente fundamental da civilização humana.

\subsection{Antônio Gonçalves da Silva, Patativa do Assaré e padroeiro dos poetas de Assaré}

Ao pensarmos, neste trabalho, a figuração mítica de Patativa do Assaré, vislumbramos sua representatividade imagética na organização social de Serra de Santana e a vinculação de sua palavra à ritualização da poesia popular, dizível e representativa da comunidade. A abordagem 'mítica' proposta, por Feitosa (2003), ergue-se significativa, pois, relaciona-se à tradição cultural representada na figura humana de Patativa, homem sertanejo que, ao cantar sua aldeia, se fez poeta e transfigurou-se em mito, atingindo a universalidade condizente à sua posição social.

Sendo o mito indispensável à cultura e sendo esta um processo em andamento, o mito nasce e renasce conforme sua própria dinâmica da cultura vai sendo alterada. A função mítica de Patativa seria a mediação entre o passado e o futuro, entre o tradicional e o moderno, entre sua juventude e sua velhice, entre o erudito e o popular. (FEITOSA, 2003, p. 249)

$\mathrm{O}$ aspecto mítico da figura de Patativa constituiu-se não só pelas produções poéticas e performáticas, mas pela sua trajetória de vida através da publicização do homem e de sua poesia. Obra que foi dada como uma construção singular permeadora de um coletivo sertanejo que ansiava por uma referência, por uma legitimação de seu existir. A poesia criou o Ser Patativa do Assaré e a midiatização dessa poesia configurou-o/legitimou-o dentro de uma 
organização sistêmica da cultura popular de massa, elevando o poeta à condição de "um homem que não pode ser visto fora da pluralidade das plateias" (Feitosa, 2003, p.255). Patativa coloca-se na História com a inteiridade de sujeito sertanejo. Poeta que transita do chão do sertão aos programas de rádios, às publicações impressas, aos auditórios lotados, conquistando, inclusive, a notoriedade literária e acadêmica por meio de poemas que misturam harmonicamente traços da "poesia matuta" e do erudito. Ocorre que o poeta encontra na legitimação do coletivo a terra fértil para o cultivo de sua percepção do mundo sertanejo, elevando uma composição imagética comum aos atores sociais daquela região.

A tríade "pessoa-poeta-mito", tal como é estabelecida por Feitosa (2003), em que se retroalimentam o agricultor de Serra de Santana, o poeta performático e o educador exemplar do sertanejo, mostra-se na cantoria de Lorival Pereira e Zé Soares durante o Encontro de Repentistas no VIII Patativa do Assaré em Arte e Cultura, configurando imagens de Patativa, ora como pessoa, ora como poeta, ora como mito.

\author{
Zé Soares - Vim cantar e visitar \\ No lugar que ele morou \\ Cantar pruma plateia \\ Que ainda não me escutou \\ E pisar na cara da terra \\ Que Patativa pisou (Transcrição da filmagem do Encontro de Repentistas durante o \\ VIII Patativa do Assaré em Arte e Cultura em março de 2012).
}

No excerto da cantoria proferida por Zé Soares, é notória a materialidade da pessoa: um homem simples que viveu no sertão do Ceará. É a figura do agricultor que nasceu e morou na localidade de Serra de Santana em Assaré-CE, extraindo da terra seu sustento, o que se privilegia nos versos acima. A imagem do homem Antônio Gonçalves da Silva, muito cedo alcunhado de Patativa do Assaré, mostra-se na estrofe abaixo de Lorival Pereira. Nela, há a representação do sujeito comum que escuta os outros cantadores e bebe cachaça com eles.

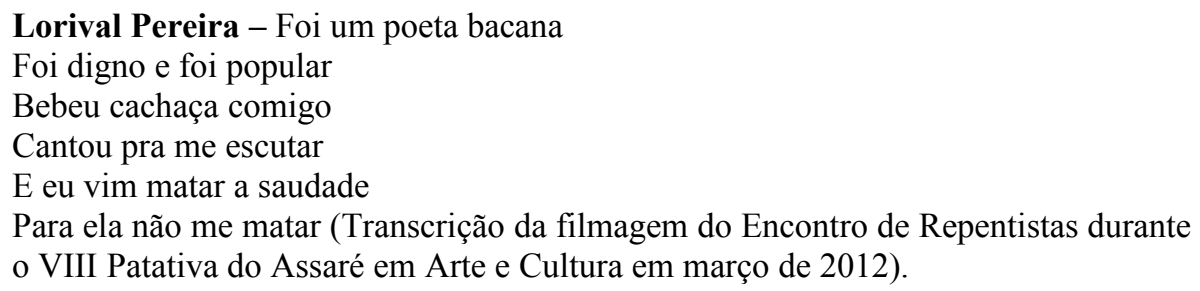

No mesmo repente, Zé Soares representa o poeta Patativa em uma figuração de sua completude poética: 
Cantou tocando viola

Pra quem bem não conhecia

Ele mostrava e controla

Mostrando que poesia

Pra ele o mundo é escola (Transcrição da filmagem do Encontro de Repentistas durante o VIII Patativa do Assaré em Arte e Cultura em março de 2012).

A acentuada completude poética de Patativa é evidenciada por Lorival Pereira. O repentista afirma que o poeta maior de Assaré conseguiu abarcar os mais variados assuntos nos seus versos.

\author{
Lorival Pereira - Falou de terra e de Deus \\ De alegria e sufoco \\ Dos castelo de ricaço \\ E dos casebre de reboco \\ E tudo é que beleza \\ Ele deixou aqui um pouco (Transcrição da filmagem do Encontro de Repentistas \\ durante o VIII Patativa do Assaré em Arte e Cultura em março de 2012).
}

Quando a imagem de Patativa do Assaré, contudo, passa a ser revestida com a ideia de que ele era um poeta completo e que sua poética universalizava o sertão, começa a transfiguração da pessoa e do poeta em mito. Zé Soares expõe a ideia de que Patativa era um grande artista, sendo maior ainda como cantador e poeta. As palavras de Soares elevam a condição de homem comum de Patativa a um patamar de condicionalidade mítica.



O tom de exaltação pode ser sentido também no repente executado por Mané do Cego e Miceno Pereira. Há a edificação e a ritualização, como apontamos antes, de uma figura mítica. Ao tempo que Mané do Cego afirma ser Patativa o pioneiro da rima; Miceno Pereira atribui-lhe a eternidade poética, o que traz a noção de (sua) permanência. Portanto, dois elementos importantes se sobressaem para a figuração mítica do poeta: a origem e a imanência. As duas estrofes que seguem atestam essa mitificação em que não existe mais o homem e o poeta, mas uma espécie de deidade, um dono da palavra, carregador dos signos sagrados do povo sertanejo, conforme os ensinamentos de Colombres (1997). 
Seu trabalho é divulgado

Por esse mundão inteiro

As coisas da poesia

Desse torão brasileiro

Miceno Pereira - Foi ele o meu companheiro

Do sertão do nhambu

Nas terras do Assaré

No meu Ceará comum

Se houver poeta eterno

O Patativa é um (Transcrição do repente sobre Patativa do Assaré, executado por

Mané do Cego e Miceno Pereira em junho de 2011).

A representação da tríade homem-poeta-pessoa ocorre nos repentes através da voz viva dos cantadores, manifestação da performance e da oralidade. Por esse motivo, é salutar voltarmos para a questão da voz, oralidade e performance a partir dos pressupostos teóricos de Paul Zumthor (2011).

\section{A voz e o canto vivos: voz, oralidade e performance nos repentes sobre Patativa do Assaré}

Se pensarmos a voz como materialidade histórica do sujeito social, estaremos diante de uma organização estruturo-funcional do imaginário de uma sociedade. A voz caracteriza-se, desta forma, como um fenômeno complexo. Desde uma perspectiva biológica, não há um aparelho de órgãos específicos para sua produção, dependendo de outros complexos orgânicos vitais para fazer-se constituída: os aparelhos digestório e respiratório. Desta forma, na complexidade do organismo humano, não existe um aparato específico para produzir uma linguagem articulada; distinção entre homens e animais. Por este motivo, a voz depreende a atração e a repulsa. Atração por ser o fator distintivo entre racionalidade e animalidade; repulsa por não poder ser aprisionada nas sistematizações em que se tentou encarcerá-la.

A voz que aqui interessa não é aquela que se reduz à produção sonora do ar que provém dos pulmões e sai pela boca, conferindo às representações gráficas sons particulares que as predicam fonemicamente. O que importa é a voz que possui uma historicidade: fenômeno global vinculado à história do homem, à sua materialidade constitutiva. Essa voz que ultrapassa a articulação oral da língua e se faz como presença viva de um corpo vivo em ação em determinado contexto (ZUMTHOR, 2000).

Para Zumthor (2000), a voz não constitui o sinônimo de oralidade, uma vez que ela extrapola o sentido linguístico de comunicação por meio da fala. A fundamentação para o estudo da voz encontra-se na história do homem, em sua edificação diacrônica, desde as origens vocais da poesia nos cantos e danças rituais, passando pelas fórmulas mágicas e narrativas míticas. Propõe, o autor, seis teses sobre a voz. Delas emergem as seguintes características: a) lugar simbólico; b) alteridade; c) 
presença dos ouvidos do enunciador e do ouvinte; d) nomadismo e movência; e) lugar na linguagem; e f) presença vocal plena somente na experiência poética.

Merecem ser elencados alguns aspectos do fenômeno vocal destacados por Zumthor (2000). O primeiro aspecto refere-se à materialidade da voz, ou seja, que ela "é uma coisa" (ZUMTHOR, 2000, p. 99), substância que existe empiricamente, constituindo como ato e não como potência etérea, portanto possui traços descritíveis e interpretáveis. O aspecto seguinte afirma que ela, a voz, "se situa entre o corpo e a palavra, significando ao mesmo tempo a impossibilidade de uma origem e o que triunfa sobre essa impossibilidade" (ZUMTHOR, 2000, p.100). O terceiro apregoa que a voz se diz, sendo ela a linguagem do sonho, já que não "se sonha a escrita; a linguagem sonhada é vocal" (ZUMTHOR, 2000, p.100). Ainda, há de se destacar dois aspectos que se ligam à alteridade: a voz como "uma forma arquetipical" - ligada para nós a um sentimento de sociabilidade", e o outro em que a voz "implica ouvido" ensejando "dois ouvidos, simultâneos, uma vez que dois pares de ouvidos estão em presença um do outro, o daquele que fala e do ouvinte" (ZUMTHOR, 2000, p.101).

É em sua obra Introdução à poesia oral, cuja edição francesa é de 1983, que Zumthor (2010) aborda o caráter de alteridade da voz. Nas palavras do medievalista convertido em estudioso da poética viva:

Indefinível, senão em termos de relação de afastamento, articulação entre sujeito e objeto, entre Um e o Outro, a voz permanece inobjetivável, enigmática, não especular. Ela interpela o sujeito, o constitui e nele imprime a cifra da alteridade. Para aquele que produz o som, ela rompe uma clausura, libera de um limite que por aí revela, instauradora de uma ordem própria: desde que é vocalizado, todo objeto ganha para um sujeito, ao menos parcialmente, estatuto de símbolo (ZUMTHOR, 2010, p. 15) (grifos nossos).

Dizentes são as palavras do autor, pois mais do que ressaltar o caráter de alteridade da voz, ensina que é através dela que os objetos do mundo adquirem um estatuto simbólico, antes desmaterializados, quase-etéreos, e quando vocalizados, signos constituintes do âmbito social. É, pois, na vocalização que o sujeito se liberta e passa a entender os objetos do mundo para além da coisificação, atribuindo a eles uma funcionalidade simbólico-estrutural.

Como observa Zumthor (2010, p. 11), a voz "ultrapassa a palavra". Isso se deve ao fato de que ela invoca a questão corpórea, já que emana de um corpo - que não é neutro; possui historicidade. Por outro lado, adquire um transcendência material ao ultrapassar o corpo de onde ela provém, uma vez que, como alerta o autor, o fenômeno vocal constitui-se em uma herança cultural, sendo, no inconsciente, uma forma arquetipical, por onde emergem possibilidades simbólicas.

Não se duvida que a voz constitua no inconsciente humano uma forma arquetipical: imagem primordial e criadora, ao mesmo tempo, energia e configuração de traços que predeterminam, ativam, estruturam em cada um de nós as experiências primeiras, os sentimentos e pensamentos. Não conteúdo mítico, mas facultas, possibilidade simbólica aberta à representação, constituindo, ao longo de séculos, uma herança cultural transmitida (e traída) com, dentro, pela linguagem e os outros códigos que o grupo humano elabora (ZUMTHOR, 2010, p. 10). 
É preciso aqui ressaltar a não-instrumentalidade da voz, como ensina Sílvia Adriana Davini (2008) no artigo Voz e palavra - música e ato. Em seu estudo, afirma que um instrumento é comparável a uma prótese que é utilizada para determinado fim, funcionando como um dispositivo técnico, escapando ao humano. A voz traz característica instrumentais, se a vislumbrarmos além da matéria corpórea e isso lhe confere uma estrutura e uma funcionalidade meta-corpórea, contudo não a relega à objetalização de um instrumento. Aliás, o limite entre corpo e instrumento é justamente aquilo que distingue o humano do inumano. Vale ressaltar que a voz é produzida por órgãos, e não é um órgão, já que não se pode confundir a composição orgânica com seu produto.

Desta forma, podemos pensar que a voz é produto do corpo, por meio dos órgãos que compõem o sistema fonatório, autonomizando-se em relação à estrutura de sua gênese. Ainda, como produção do corpo a voz emana do sujeito, que só existe corporificado, ou seja, na sua natureza somática.

Um instrumento é uma ferramenta, uma prótese que utilizamos para um dado fim, não é nem pode ser humano. Os limites entre corpo e instrumento são os limites entre o humano e o não humano. Um órgão é parte de um sistema organizado em torno de certas funções, ou seja, de um "organismo". O sistema fonatório está constituído por órgãos cuja função é produzir voz e palavra. Assim, a voz não pode ser confundida com o que produz. Por si só, um instrumento não pode ocultar, nem um órgão pode revelar nada. É o sujeito quem oculta ou revela; e o lugar do sujeito é o corpo. Em consequência, não podemos pensar a voz e a palavra sem pensar o corpo e o sujeito (DAVINI, 2008, p. 312).

Concebida para além das limitações de uma compreensão instrumental, em conjunto com a palavra, a voz é impensável sem corpo e sujeito assim como a existência do sujeito é dada, estruturada e configurada pela voz. Contudo, como compreende a semiótica teatral, a voz é marcada por polaridades nitidamente determinadas. Advêm dicotomias como corpo versus signo, constituindo-se como jogo antitético, resultando que de uma polaridade à outra se constitua um entre vazio. Entretanto, ao materializar-se em corpo, a voz opera um movimento de ruptura com tais polaridades.

\footnotetext{
A ideia de voz como um meio, dominante no campo da semiótica teatral, pressupõe a existência de polaridades claramente definidas, tais como corpo e signo, um e outro, entre as quais fluem voz e palavra, de acordo com as exigências de uma e outra polaridade. Nesse sentido, a voz configura um entre vazio, um mero trânsito. Ao materializarmos esse entre, as polaridades desmoronam, não há mais intenção/voz, interno/superficial, corpóreo/incorpóreo. Há corpo, que produz fluídos, magnetismo, calor, onda, partículas, imagem, olhar, voz; um corpo-palco da primeira confluência entre dimensão visual e acústica da cena (DAVINI, 2008, p. $312)$.
}

As ideias de Davini (2008), mesmo que ligadas especificamente ao campo dramático, confluem às concepções de Zumthor, uma vez que entendem a voz como tendo seu lugar e materialidade histórica no corpo e no sujeito. A autora entende a voz como uma produção do corpo que se encontra na mesma categoria do movimento, mas, de certa forma, é maior que o movimento por 
comportar a palavra e o discurso. Nas palavras de Davini (2008, p. 312), “[...] consideramos a voz como produção do corpo, na mesma categoria que o movimento. Porém, por constituir-se em lugar da palavra, a voz comporta uma capacidade de definição discursiva muito maior que o movimento".

Ruth Finnegan (2008) dá suporte à visão de que a voz se constitui no corpo. A estudiosa ensina que a voz é mais que um mero meio de transporte de textualidade, daí sua negação da instrumentalidade da voz; ela seria parte da própria substância textual que transporta. São as palavras da autora que dizem que

Aqui, a voz é mais que mero condutor de textualidades preexistentes, sejam verbais ou musicais. De modo frequentemente negligenciada em relatos acadêmicos, mas ressaltado em textos aqui [na obra conjunta Palavra cantada], a voz é, ela mesma, em sua presença melódica, rítmica e modulada, parte da substância. Pois a "letra" de uma canção em certo sentido não existe a menos e até que seja pronunciada, cantada, trazida à tona com os devidos ritmos, entonações, timbres, pausas; tampouco a canção tem "música" até que soe na voz. Aqui, canção e poesia oral significam a ativação corporificada da voz humana [...] (FINNEGAN, 2008, p. 24).

Após a definição da voz para além de uma compreensão instrumental que desconsidera a sua imbricação com a historicidade do corpo - não só o do locutor (enunciador), mas também o do interlocutor (enunciatário) -, é preciso voltar-se para os conceitos de oralidade, vocalidade e performance. A oralidade como algo que ultrapassa a mera exposição oral, é entendida por Zumthor (2010, p. 35-36) em "quatro espécies ideais". Essas corresponderiam: a) oralidade primária ou pura, em que, praticamente, inexiste o contato com a escrita; b) oralidade mista, em que a influência da escrita constitui-se como remota e fraca; c) oralidade secundária, marcada pela influência da escrita; e d) oralidade mecanicamente mediatizada, própria das reproduções pela técnica nos meios de comunicação, tal qual ocorre nos $c d s$ e $d v d s$ que apresentam espetáculos musicais, por exemplo.

Nos repentes registrados nas duas viagens a Assaré-CE $\mathrm{CE}^{4}$, emergem a oralidade primária. Essa é constituída pelo próprio ato da improvisação: Mané do Cego, Miceno Pereira, Lorival Pereira e Zé Soares promovem disputas poéticas "de repente" com o intuito de homenagear Patativa do Assaré: assoma desse movimento uma oralidade sem uma aparente influência direta da escrita, performatizada em "cantigas ao desafio". Há momentos no primeiro repente executado pela dupla em frente à casa em que Patativa do Assaré morou em que fica clara a manifestação e o reforço de uma oralidade primária, como, por exemplo, no trecho abaixo, através da repetição verbo cantar.

\footnotetext{
Zé Soares - Vim cantar e visitar No lugar que ele morou

Cantar pruma plateia

Que ainda não me escutou

E pisar na cara da terra

Que Patativa pisou
}

${ }^{4}$ Realizou-se duas viagem para a pesquisa de campo em Assaré-CE em junho de 2011 e março de 2012. 


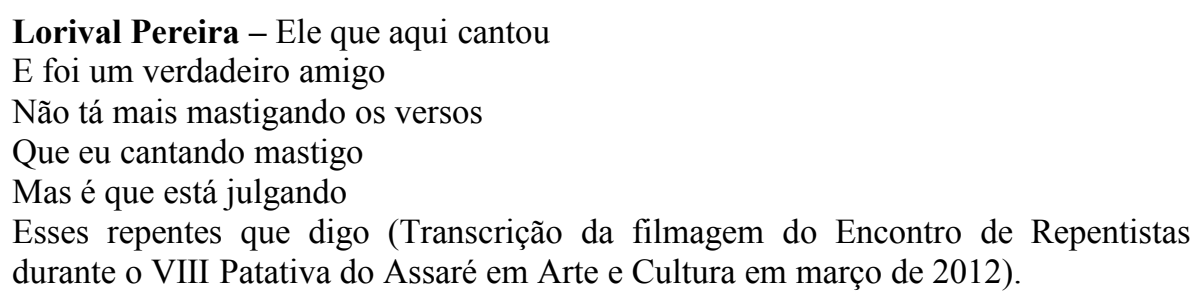

É também importante falar sobre a dupla oralidade que permeia o repente de Mané do Cego e Miceno Pereira. Isso se deve às condições particularizantes em que se dá a performance: um programa da rádio Assaré FM, registrado na pesquisa de campo. Há uma recepção direta pelo pesquisador que registra o repente em vídeo e pela operadora da emissora, contato direto com a oralidade primária. Há, também, a recepção dos radiouvintes, que são atingidos pela mediação eletrônica, manifestando-se uma oralidade mediatizada. Ademais, poder-se-ia problematizar a possiblidade de uma oralidade secundária ou mista, uma vez que, mesmo que evoquem as experiências que tiveram com o poeta, inclusive acompanharam sua enunciação em performance, a produção poética que os cantadores naquele momento realizam é bem provável que tenha sofrido influência da poesia de Patativa do Assaré que foi registrada em livro.

Apesar de categorizar a oralidade nas quatro espécies ideais, o autor considera o conceito como redutor, pois este não compreende a vivacidade da manifestação poética que advém por meio da voz, remetendo somente à constituição sonora. Para fugir ao reducionismo do termo oralidade, Zumthor (2010) utiliza a expressão vocalidade que corresponderia à palavra poética enquanto voz viva que se une ao corpo, desencobrindo-se como presença sonora, gestual e cênica. Enquanto a oralidade fica restrita à expressão oral, a vocalidade é mais ampla, uma vez que inclui os outros aspectos, além dos sonoros, que permeiam a realização do ato de transmissão oral; a vocalidade, nos dizeres do estudioso, "é a historicidade de uma voz: seu uso" (ZUMTHOR, 2010, p. 21) e a compreensão da voz em uso não se restringe ao fenômeno puramente sonoro.

Finnegan (2008, p. 28) partilha da preferência de Zumthor pela expressão vocalidade em detrimento de oralidade. Ao afirmar que "todas as culturas reconhecem uma variedade de 'gêneros orais"”, ela expõe que "preferiria chamar de 'gêneros vocalizados"”. A noção de vocalidade trazida por Zumthor é compreendida mais facilmente com a ajuda de Davini (2008). Ela percebe que a vocalidade se realiza tal qual a voz em sua condição de manifestação transindividual e histórica. De acordo com a autora,

O conceito de vocalidade, tal como definido por Paul Zumthor, vem superar o caráter individual e a-histórico dominante nos discursos vinculados à produção de voz e palavra em performance, considerando também a palavra do outro, dos outros 
em sua contingência social e histórica. Nesse sentido, entendemos por vocalidade a produção da vOz e palavra por parte de um grupo dado em um tempo e lugar determinados (DAVINI, 2008, p. 313).

Está evidente no fragmento que Davini (2008) se refere à vocalidade como uma manifestação ligada à performance. Para Zumthor (2010, p. 31),

[..] é a ação complexa pela qual uma mensagem poética é simultaneamente, aqui e agora, transmitida e percebida. Locutor, destinatário, circunstâncias (quer o texto, por outra via, com a ajuda dos meios linguísticos, as represente ou não) se encontram concretamente confrontados, indiscutíveis. Na performance se redefinem os dois eixos da comunicação social: o que junta o locutor ao autor; e aquele em que se unem a situação e a tradição.

Na passagem escrita por Zumthor (2010), a performance aparece como momento em que a voz toma plena vivacidade e historicidade e se realiza na relação do "eu" que pronuncia o poema com o "outro" que o recebe; é onde se manifesta aquela alteridade que o teórico suíço identifica na voz. Nessa ação, há dois eixos comunicacionais que se reconfiguram: o eixo do autor-locutor e o eixo da situação-tradição. Pode-se dizer que a redefinição que ocorre entre o autor-locutor se dê pelo fato de o locutor que põe o poema em performance nem sempre seja o autor do poema, sem embargo, ao impostá-lo em sua voz feita em corpo, por meio de toda uma gestualidade que pode entrar em jogo, ele acaba por redimensionar a recepção do texto, marcando-o com a sua interpretação e, de certa maneira, adquire um estatuto de autoria. Há, portanto, no movimento performático, a assunção do autor e de sua condição de sujeito falante. Já na questão da situação e tradição, um poema pode estar imbuído de significados que estão presos à tradição, mas que, no interior da situação performática, são subvertidos e são permeados por novos sentidos.

O estudioso português Carlos Nogueira (2007, p. 41), ao falar das cantigas ao desafio lusitanas, afirma que tradição e inovação convivem no ato da performance. Segundo ele, as formas "poéticas convivem geralmente com formas musicais já antigas, tradicionais, construtoras, ambas, de um produto poético-musical sempre renovado e irrepetível".

Além disso, a performance, como alerta Finnegan (2002, p. 35), engendra mais que "um evento acústico", podendo "lançar mão simultaneamente de uma série de recursos multimodais", isso significa que "O visual, o somático, o gestual, o teatral, o material - tudo pode fazer parte" da performance. Assim, o ato performático engendra não só os elementos linguísticos que atuam na transmissão do poema, mas aqueles, denominados de formas sóciocorporais, por Zumthor (2010, p. 86), que se ligam aos corpos que estão envolvidos na situação. 
Quanto às formas não linguísticas, eu as agrupo como "sócio-corporais": entendo por isso o conjunto de características formais ou de tendências formalizadoras que resultam em sua origem ou finalidade da existência do grupo social, e da presença e sensorialidade do corpo: ao mesmo tempo, o corpo fisicamente individualizado de cada uma das pessoas engajadas na performance e aquele, mais dificilmente discernível porém bem real, da coletividade que se manifesta em reações afetivas e movimentos comuns (ZUMTHOR, 2010, p. 86).

Também, é preciso dizer que formas linguísticas e não linguísticas da performance, assim como a própria performance, não são elementos meramente estruturais da representação oral (ou vocal) do poema, mas também elementos significativos. Quando Zumthor (2010, p. 85) afirma que "A performance é, pois, tanto um elemento importante da forma quanto constituinte dela" e acrescenta que à sonorização - ocorrida no ato performático - "o texto reage e se adapta, modifica-se", ele parece estar dizendo que tanto formas linguísticoauditivas como formas corpóreo-gestuais, entre outros elementos constituintes da performance, influem diretamente na transmissão e na recepção do poema, ou seja, interferem em seu estatuto semântico.

As formas linguísticas e extralinguísticas utilizadas pelo poeta em performance adaptam-se ao público, conforme Nogueira (2007, p. 44-45) . Ressalta-se, com isso, a alteridade da interpretação poética, mostrando que o público assume um importante papel no jogo textual que se estabelece com a interpretação, podendo assumir um papel de coautoria do poema.

\footnotetext{
$\mathrm{Na}$ dramatização codificada configurada pelo desafio, a adaptação do texto ao ouvinte faz-se durante a performance. Na execução do poema, diversas marcas linguísticas, paralinguísticas ou gestuais assinalam as interações entre o emissor e assistência, contribuindo com o arranjo dramático da performance, estabelecendo um ambiente de conivência entre as duas partes.

$[\ldots]$

O poeta-intérprete altera o discurso, o tom, a entoação, o timbre de voz e os gestos, de acordo com a recepção que pressente e percebe no auditório.
}

A influência do auditório sobre o enunciador é perceptível no corpus deste trabalho. Após o término do primeiro repente sobre Patativa do Assaré no Encontro de Repentista em Serra de Santana (Assaré-CE), Mané do Cego toma a palavra, agradecendo aos versos improvisados por Lorival Pereira e Zé Soares. O "mestre de cerimônias" pretende, naquele momento, passar a palavra para o professor Luizão. No entanto, Ribinha, uma das pessoas presente no público, pede um mote à dupla de cantadores, o que resulta na execução do segundo desafio entre eles.

Mané do Cego - Você ouviu aí a dupla Lorival Pereira e Zé Soares, fazendo a abertura deste maravilhoso evento na casa do poeta maior Patativa do Assaré, saudando a família, saudando os amigos. E por que não, registrar a presença do 
nosso prefeito Evanderto que chegou agora. E então, Lorival, é aqui que estamos matando a saudade de 1983 lá na Ribeira de São Miguel, onde a gente fez uma cantoria, eu, você e Chico Crisântemo. Está presente também o meu amigo Ribinha, esse que é divulgador da cultura de Sul a Norte, de Norte a Sul e em todos os recantos do país. E agora vou passar o microfone para o professor Luizão...

Lorival Pereira - Atendendo aqui a nosso amigo Ribinha, ele está pedindo o mote. Ribinha eu conheci em São Paulo. Meu amigo, meu irmão, muito obrigado. Ele está pedindo o mote dizendo: "A terra de Patativa:/ o berço da poesia". Ribinha....

(Zé Soares para Lorival Pereira: Começa!)

Lorival Pereira - Tornou-se autoridade

Nesse nosso interior

Fez poema de amor

De ausência e de saudade

Com sua simplicidade

Descrevi todo dia

E sua diplomacia

O céu daqui não lhe priva

A terra de Patativa:

O berço da poesia (Transcrição da filmagem do Encontro de Repentistas durante o VIII Patativa do Assaré em Arte e Cultura em março de 2012).

No excerto se explicita claramente que a disputa poética passa por combinações realizadas entre os contendores. Ao dirigir-se para Lorival Pereira e indicar que ele deveria começar o repente, há indicação por Zé Soares de que a regra que regerá o embate é a pacificidade, ao contrário do que acontece em muitos desafios, de acordo com o que ensina Nogueira (2007). O tom "pacífico" advém de que o momento em que os dois cantadores emitem a sua voz pressupõe uma homenagem a Patativa do Assaré; o cantador e poeta que deve sair vencedor do "cantar ao desafio" entre Pereira e Soares não é nenhum dos dois, mas o poeta de Assaré: o momento é de comemoração pelo aniversário do saudoso poeta popular.

Podemos pensar, aqui, que o próprio ato de tomar a palavra é carregado por uma nuance persuasiva que enquadra a performance em um sentido do texto, através dos recursos linguísticos ou não linguísticos utilizados pelo locutor na sua enunciação poética, para o receptor. Segundo Zumthor (2010, p. 30), “a intenção do locutor que se dirige a mim não é apenas a de me comunicar uma informação, mas de consegui-lo, ao provocar em mim o reconhecimento dessa intenção, ao submeter-me a força ilocutória de sua voz".

Ainda, de acordo com Zumthor (2010, p. 32), o ato performático "constitui o momento crucial em uma série de operações logicamente (mas nem sempre de fato) distintas" que são as cinco fases "da existência do poema". As cinco fases e as que participam da performance são definidas da seguinte forma:

1) produção,

2) transmissão,

3) recepção,

4) conservação,

5) (em geral) repetição. 
A performance abrange as fases 2 e 3; em caso de improvisação, 1,2 e 3.

É preciso, agora, que se detenha nessas fases, explorando um pouco o seu significado e importância. A primeira etapa diz respeito ao ato criador em si em que o poeta, para usar a imagem parnasiana de Bilac (1996, 253), “Torce, aprimora, alteia, lima/ A frase”. Isso não quer dizer que o poeta se coloque na impassividade e na solidão do claustro, nem que ele busque a perfeição formal; significa que este se constitui o ato de construção. A segunda corresponde ao momento em que a mensagem poética é enunciada, para usar o termo de Jakobson (2003), através de um canal. A terceira diz respeito a quando o interlocutor põe a decifrar os códigos que compõem a fase 2. A quarta abrange as formas de como a obra se perpetua, sendo muitas vezes tributária da reiteração que se caracteriza como última etapa do processo de existência do poema.

A performance corresponderia, como já enunciado por Zumthor (2010), à transmissão e recepção do poema e, quando ele é construído na improvisação, também à produção. Assim, seja o repente enunciado por Mané do Cego e Miceno Pereira ou os dois performatizados por Lorival Pereira e Zé Soares contemplam as três primeiras fases da existência do poema (produção, transmissão e recepção). A fase 4, ou seja, a conservação dá-se pelo registro em vídeo feito durante o ato de pesquisa e pela transcrição e posterior divulgação do trabalho de campo. Em tempo: quando o registro em vídeo da performance dos cantadores passa a ser retransmitido pelos pesquisadores na divulgação do trabalho, a oralidade primária cede lugar à oralidade mediatizada; a recepção passa a ocorrer através de meios eletrônicos e não mais através do contato direto com a performance improvisativa dos repentistas. No fazer dos cantadores, está manifesta uma tradição do improviso que, de acordo com Cascudo (s/d), remonta aos pastores da Grécia clássica. Contudo, conforme Nogueira (2007), a estabilização do modelo deu-se com os trovadores medievais. Desta forma, mesmo não podendo aventar as origens como lusitanas, arrisca-se a dizer que há uma tradição do repente, como atestam autores como Joaquim Norberto de Sousa Silva (2002), na poética lusófona. Tradição que pode ter tido influência de fontes árabes como observa Luis Soler (1978, p. 18):

[...] comecei a notar que, apesar de bem brasileiras, aquelas vivências artísticas e culturais [o contato com o repente e a participação na Orquestra Armorial], como um todo, não eram nada estranhas a minha hispanidade de origem. [...] comecei a reparar que, na hora de serem evocadas genealogias e ascendências, dentro de um painel onde não faltavam jesuítas, trovadores, lendas cristãs medievais, e tudo o mais, ficava quase invisível uma figura que eu achava que deveria dominar todas as restantes: o árabe. O árabe, com sua inseparável cantilena poética, espécie de necessidade visceral, perenemente sentida; supremo meio de comunicação social e de integração racial, para ele. Com sua borbulhante lírica nascendo, mais que do intelecto, do telurismo que envolve a vida humana, dos excessos do coração e da 
fantasia. A velha e inconfundível tradição poética do beduíno do deserto, em soma, transmitida aos povos com os quais foi conviver e só a eles. Tradição da qual eu conhecia remanescentes espanhóis, irmãos dos aqui imperantes.

Albert Hourani (2001, p. 30) corrobora a posição de Soler (1978) de que o cultivo na cultura árabe de uma poética que possuía em vista a vocalidade e o improviso:

\begin{abstract}
Os poemas, porém, eram compostos para recitação em público, seja pelo próprio poeta, seja por um rawi, ou declamador. Isso tinha algumas implicações: o sentido precisava ser transmitido num verso, uma unidade única de palavras cujo sentido fosse captado pelos ouvintes, e toda apresentação era única e diferente das outras. $\mathrm{O}$ poeta ou rawi tinha margem para improvisações, dentro de um esquema de formas e modelos verbais comumente aceitos, do uso de certas palavras para expressar certas idéias e sentimentos. Assim, talvez não tenha havido uma versão autêntica única de um poema. Como nos chegaram, as versões foram produzidas mais tarde por filólogos ou críticos literários, à luz das normas linguísticas ou poéticas de sua época.
\end{abstract}

Fora toda a questão da origem e da influência árabe - dado que ainda procuraremos investigar em outros trabalhos -, há referências, nos três repentes, não só ao próprio ato do improviso que é executado como também aquele que foi realizado por Patativa do Assaré ao longo de sua vida poética. No repente performatizado por Mané do Cego e Miceno Pereira, enquanto este recorda a vivência na cantoria junto com o poeta maior de Assaré, aquele insinua que, após a morte, Patativa está no paraíso fazendo repentes junto com Jesus Cristo.

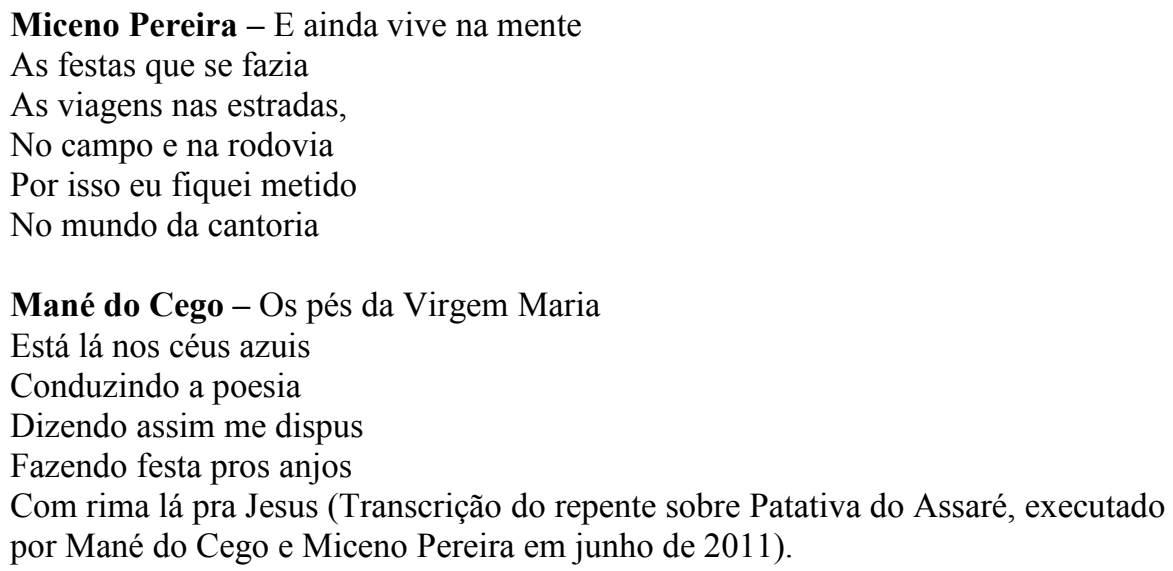

A perspectiva da cantoria realizada em conjunto com o Patativa já é enunciada por Miceno Pereira no depoimento dado antes da execução do repente:

Miceno Pereira - Seguinte, como o colega falou, é verdade pura, o Patativa, eu frequentei muitas vezes a casa dele. Cantei muitas vezes com ele, viajamos juntos, viajando a cavalo naquela época em que os transportes eram difíceis. Nós viajávamos a cavalo pelo sertão, fazendo cantoria nas casas dos amigos, nas renovações, festas de casamento. Tudo que era evento, nós estávamos juntos no caso de três ou quatro anos. Depois, aqueles acidentes que ele sofreu, ele parou de cantar 
e eu continuei a vida com os outros cantadores, cantando e encantando o sertão, como disse o poeta. (Depoimento de Miceno Pereira, recolhido em 28 jun. 2011 na rádio Assaré $\mathrm{FM}$ ).

Lorival Pereira e Zé Soares também abordam a perspectiva do improviso. Eles abrem o Encontro de Repentistas ocorrido durante o VIII Patativa do Assaré em Arte e Cultura, falando da sua própria performance que ocorre naquele momento e a de Patativa do Assaré que surge através da reminiscência.

\author{
Lorival Pereira - Venho pra cantar repente \\ E o sal que mais me cativa \\ Essa lembrança perfeita \\ Eu acho que bem que viva \\ Para falar da saudade \\ Que sinto de Patativa
}

Zé Soares - Eu acho de Patativa

Um grande nome fiel

Um artista repentista

Que não manchou o papel

O maior nome até hoje

Da cultura de cordel

Lorival Pereira - Foi digno, forte e fiel

E cantou como violeiro

Falou das coisas da terra

De fazenda e de vaqueiro

Deixou deixando saudade

Para nós e o mundo inteiro (Transcrição da filmagem do Encontro de Repentistas durante o VIII Patativa do Assaré em Arte e Cultura em março de 2012).

A abordagem dos repentes demonstra a voz viva em plena execução: o homem materializado na palavra que sempre o ergueu. $\mathrm{Na}$ voz que o fez poeta de seu povo. $\mathrm{Na}$ poética que lhe atribuiu modelar figuração. Através dessa voz, emana a performance não só daqueles que a executam no momento da pesquisa de campo, mas também da de Patativa do Assaré que, seguindo Carvalho (2009), continua a ecoar sertão adentro.

\title{
4 Considerações finais
}

A figura de Patativa do Assaré e sua poética são incontestes no sertão brasileiro. Sua voz ecoa por todos os cantos, trazendo o imaginário sertanejo em sua versificação do cotidiano; elevando o signo da emergência sertaneja a um patamar universalizante. A condição de trânsito referencial alcançada por sua poética teve uma funcionalidade importantíssima se vislumbrarmos os movimentos de aglomeração desses cantadores, como os aqui citados, em torno de uma comunidade muito mais imaginada que factual. Sua voz 
performática, de acordo com os ensinamentos de Zumthor, somada às condições de divulgação de sua poética solidificaram não só a imagem do poeta, mas um espaço antes em desencanto. Edificaram um sujeito poético que traz em si não só o campo imagético sertanejo, e todo influxo cultural formador, mas a materialidade do espaço constituído e constituidor do nordeste de nosso país. Dos sujeitos componentes da ossatura dialógica de nossa cultura.

\section{Referências:}

ARISTÓTELES; HORÁCIO; LONGINO. A poética clássica. São Paulo: Cultrix, 1997.

ARMSTRONG, K. Breve história do mito. São Paulo: Cia das Letras, 2005.

BILAC, Olavo. Olavo Bilac: obra reunida. Rio de Janeiro: Nova Aguilar, 1996.

BRISSON, Luc. Introduction à la philosophie du mythe. Vol. I Sauver les mythes. Paris: Vrin, 1996.

CARVALHO, Gilmar de. Cem Patativa. Fortaleza: Omni, 2009.

COLOMBRES, Adolfo. Celebración del linguaje: hacia uma teoría intercultural de la literatura. Buenos Aires: Ediciones del Sol, 1997.

DAVINI, Adriana. Voz e palavra - música e ato. In: Matos, Cláudia Neiva de et al (org.).Palavra cantada: ensaios sobre poesia, música e voz. Rio de Janeiro: 7Letras, 2008.

ELIADE, M. Mito do eterno retorno. São Paulo: Mercuryo, 1992.

Mito e realidade. São Paulo: Perspectiva, 1994.

CASSIRER, E. O mito do Estado. Lisboa: Europa-América, 1961.

. Linguagem e mito. São Paulo: Perspectiva, 1972.

FEITOSA, Luis Tadeu. Patativa do Assaré: a trajetória de um canto. São Paulo: Escrituras, 2003.

FINNEGAN, Ruth. Performance, poesia, música: o que vem primeiro. In: Matos, Cláudia Neiva de et al (org.).Palavra cantada: ensaios sobre poesia, música e voz. Rio de Janeiro: 7Letras, 2008.

HOURANI, Abert. Uma história dos povos árabes. São Paulo: Companhia das Letras, 1994. JAKOBSON, Roman. Linguística e comunicação. 22. ed. São Paulo: Cultrix, 2003.

NOGUEIRA, Carlos. Cantigas ao desafio e estetização da fala: natureza, modalidades e funções. Organon, Porto Alegre, janeiro-junho, 2007 p. 33-56. 
SILVA, Joaquim Norberto de Sousa. História da literatura brasileira e outros ensaios. Rio de Janeiro: Zé Mário Editor, 2002.

SOLER, Luis. As raízes árabes na tradição poético-musical do sertão nordestino. Recife: Universitária, 1978.

ZUMTHOR, Paul. Introdução à poesia oral. Belo Horizonte: UFMG, 2010. 